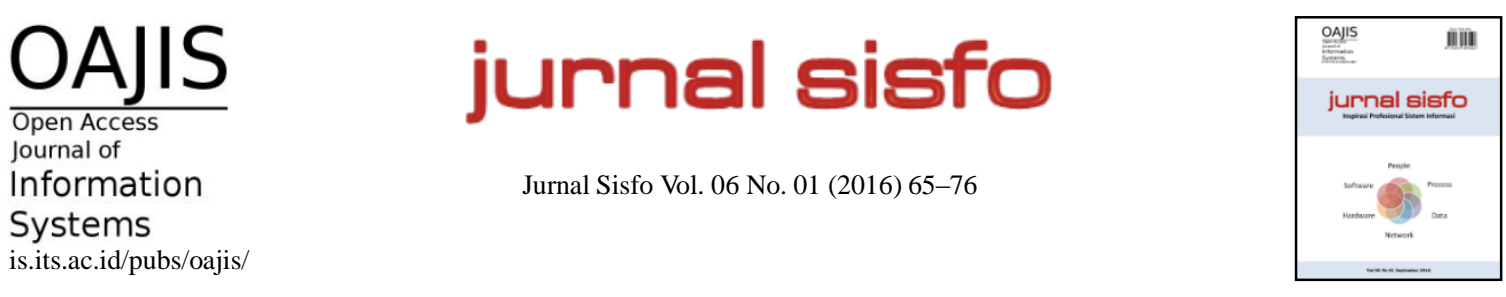

\title{
PDITS: Aplikasi Pangkalan Data Terpadu untuk Mendukung Integrasi Multi Sistem Informasi di Lingkungan Institut Teknologi Sepuluh Nopember
}

\author{
Diana Purwitasari ${ }^{\mathrm{a}, *}$, Umi Laili Yuhana ${ }^{\mathrm{a}}$, Arief Rahman ${ }^{\mathrm{b}}$, Bambang Setiawan $^{\mathrm{c}}$, Achmad Affandi $^{\mathrm{d}}$ \\ ${ }^{a}$ Teknik Informatika, ${ }^{b}$ Teknik Industri, ${ }^{c}$ Sistem Informasi, ${ }^{d}$ Teknik Elektroi, Institut Teknologi Sepuluh Nopember (ITS), Surabaya
}

\begin{abstract}
Activities of learning and teaching in higher education must be reported to the integrated national database of higher education called Pangkalan Data Pendidikan Tinggi (PDPT), in Indonesian language, as a form of public accountability reports. Institut Teknologi Sepuluh Nopember (ITS) has developed some information systems in order to support education and other related services for stakeholders like students, lecturers, staffs and managements.Here, data repository called PDITS (pangkalan data terpadu ITS, in Indonesian language), based on single entry multi purpose application concept, that integrates a lot of data coming from those multi information systems is explained in details. This paper explained about a way to integrate data from multi information systems by querying data and transforming data into data repository called PDITS. Then, data within PDITS are processed according to specific needs of other information sistems. PDITS system has three easy main steps which are interfaces for Importing, Validating and Processing such as even non technical staff can use those interfaces of PDITS. However, improvements are still necessary for the next steps to make integration with more information systems within ITS.
\end{abstract}

Keywords: data repository, pdits, data integration

\begin{abstract}
Abstrak
Penyelenggaraan pendidikan di perguruan tinggi wajib dilaporkan ke Pangkalan Data Pendidikan Tinggi (PDPT) yang terintegrasi secara nasional sebagai bentuk akuntabilitas publik layanan pendidikan. Untuk mendukung proses bisnis kegiatan pendidikan Institut Teknologi Sepuluh Nopember (ITS) telah mengembangkan banyak sistem informasi. Data-data pada masing-masing sistem diintegrasikan di suatu pangkalan data terpadu ITS disebut PDITS sesuai konsep satu kali entri data untuk banyak pemanfaatan yang membantu dalam pelaporan ke PDPT. Pada makalah ini diuraikan suatu cara mengintegrasikan data dari beberapa sistem informasi dengan melakukan penarikan data dan penyesuaian data tersebut ke model basisdata terpusat PDITS. Selanjutnya pemanfaatan data ke sistem informasi lain dilakukan dengan memproses data PDITS ke format data sesuai kebutuhan. Hasil sistem PDITS yang meliputi tiga tahap utama: Impor, Validasi dan Proses menunjukkan kemudahan sistem integrasi sehingga dapat dilakukan oleh staf non teknis. Meskipun demikian pengembangan masih perlu dilakukan untuk integrasi dengan lebih banyak sistem informasi lainnya.
\end{abstract}

Kata kunci: pangkalan data terpadu, pdits, integrasi data

(C) 2016 Jurnal SISFO.

Histori Artikel : Disubmit 3 Agustus 2016; Diterima 1 September 2016; Tersedia online 2 September 2016

${ }^{*}$ Corresponding Author

Email address: diana@if.its.ac.id; diana.purwitasari@gmail.com (Diana Purwitasari) 


\section{Pendahuluan}

Kemajuan teknologi informasi telah dimanfaatkan untuk menunjang proses bisnis dalam sebagian besar instansi di Indonesia termasuk instansi pemerintah seperti sistem aduan online masyarakat yang bisa terpantau langsung dari perangkat bergerak milik petugas pemerintah daerah [1] maupun dunia pendidikan dengan pengembangan sistem klasik yaitu sistem informasi akademik di perguruan tinggi yang memiliki fitur pendukung untuk kegiatan akreditasi [2]. Namun sistem informasi hanyalah awal dari pemanfaatan teknologi informasi karena hal yang lebih penting adalah data tercatat melalui transaksi sistem dikelola sedemikian hingga agar dapat memberikan nilai tambah bagi instansi tersebut. Oleh karena itu instansi pemerintah khususnya perguruan tinggi di Indonesia, berdasarkan Undang Undang No. 12/2012 tentang Pendidikan Tinggi, wajib melakukan pelaporan terkait penyelenggaraan pendidikan tinggi ke Pangkalan Data Pendidikan Tinggi (PDPT) yang terintegrasi secara nasional dan dikelola oleh Kementerian Riset, Teknologi dan Pendidikan Tinggi (RISTEKDIKTI). PDPT akan memberikan nilai tambah dengan fungsinya sebagai sumber informasi bagi lembaga akreditasi, pemerintah serta masyarakat sebagai salah satu bentuk akuntabilitas publik layanan pendidikan yang mendukung kebijakan nasional untuk penjaminan mutu pendidikan tinggi.

Data terintegrasi $\mathrm{PDPT}^{\dagger}$ diharapkan dapat dimanfaatkan untuk pelaporan, akreditasi serta hibah perguruan tinggi dan penelitian dosen tetap. Sampai saat ini RISTEKDIKTI telah menggunakan data PDPT ke beberapa sistem berbeda yang mendukung proses bisnis kementerian antara lain pengajuan hibah

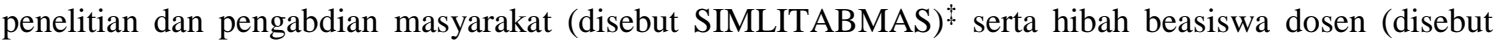
Sistem BUDI) ${ }^{\S}$. Data PDPT menyimpan data master dosen antara lain Nomor Induk Dosen Nasional (NIDN) atau Nomor Urut Pengajar Nasional (NUPN), nama dosen, jabatan fungsional, serta pendidikan tertinggi. Integrasi data PDPT pada SIMLITABMAS dapat membatasi hak dosen dalam pengajuan skema proposal disesuaikan dengan jabatan fungsional dan pendidikan terakhir. Kemudian data-data hibah penelitian dan pengabdian yang diterima seorang dosen dalam SIMLITABMAS akan dikirimkan ke PDPT sehingga terlihat pada profil dosen tersebut. Proses bisnis yang sama juga berlaku untuk Sistem BUDI. Beberapa sistem informasi dimungkinkan dikelola oleh unit kerja RISTEKDIKTI berbeda. Oleh karena itu konsep yang digunakan adalah pangkalan data terpadu mendukung integrasi multi sistem informasi di level data.

Institut Teknologi Sepuluh Nopember (ITS) telah mengembangkan banyak sistem informasi untuk membantu penyediaan kegiatan pendidikan bagi mahasiswa antara lain Sistem Informasi Akademik (SIAKAD-ITS) dan Sistem Informasi Kepegawaian (SIMPEG-ITS). Permasalahan dari banyak sistem informasi adalah terbentuknya basis data yang sangat dimungkinkan memiliki redudansi data. Data-data dari multi sistem informasi tersebut diintegrasikan di suatu pangkalan data terpadu ITS disebut PDITS untuk membantu pengguna yang cenderung enggan melakukan entri data berulang kali. Makalah ini membahas tentang perancangan, implementasi dan manfaat PDITS yang bisa diberikan kepada pemangku kepentingan (stakeholders) ITS yaitu mahasiswa, dosen, manajemen serta masyarakat sebagai suatu solusi untuk menangani redudansi data.

\section{Tinjauan Pustaka}

Perguruan tinggi di Indonesia pada umumnya telah memiliki sistem informasi akademik yang membantu proses bisnis pelaksanaan kegiatan belajar mengajar seperti pengambilan mata kuliah mahasiswa di awal semester dan input nilai yang dilakukan dosen. PDPT meminta setiap perguruan tinggi untuk melakukan pelaporan data-data antara lain sebagai berikut:

\footnotetext{
† http://forlap.ristekdikti.go.id/

${ }^{\ddagger}$ http://simlitabmas.ristekdikti.go.id

$\S$ http://budi.ristekdikti.go.id
} 
1) Data master mahasiswa dan data master mata kuliah,

2) Data mata kuliah ditawarkan, mata kuliah diambil mahasiswa dan nilainya pada semester berlangsung,

3) Selain itu juga data status mahasiswa jika telah lulus, mengambil cuti atau tidak aktif.

Oleh karena itu untuk keperluan pelaporan ke PDPT maka perguruan tinggi akan menyesuaikan data yang telah tersimpan di struktur sistem akademik serta beberapa sistem informasi lain dengan struktur data pada PDPT. Penyesuaian tersebut dapat berupa penggunaan teknologi web service untuk pengiriman data dari perguruan tinggi ke PDPT maupun penggunaan model arsitektur teknologi informasi berbasis cloud computing [3] [4] [5].

Isu integrasi data sudah ada sejak beberapa dekade terakhir berawal dari adanya kebutuhan informasi yang akan dimudahkan jika tersedia dari satu pintu namun memerlukan kombinasi data-data dari berbagai sumber sistem informasi [6]. Alternatif integrasi tersedia antara lain integrasi antar muka, integrasi aplikasi, integrasi manajemen data, serta integrasi data [7]. Banyak sistem informasi dapat memiliki perbedaan seperti pengunaan perangkat keras, sistem operasi, basis data, antar muka, proses bisnis dan aspek lainnya sehingga alternatif solusi yang lebih mudah dilakukan adalah integrasi data. Integrasi sistem dan data mudah dilakukan jika menggunakan solusi third party [8] yang sudah tersedia namun tidak mudah diimplementasikan karena keterbatasan anggaran. Perguruan tinggi Indonesia umumnya mengembangkan sistem informasi sesuai prioritas kebutuhan dan seringkali tidak terintegrasi karena belum ada masterplan teknologi informasi. Solusi yang dapat dipilih apabila sistem informasi sebagai pendukung bisnis utama telah dibangun terlebih dahulu, seperti sistem informasi akademik, sistem informasi kepegawaian, sistem informasi keuangan, adalah mengembangkan suatu pangkalan data yang menarik data-data dan divalidasi dari sistem informasi utama. Kemudian untuk kebutuhan fitur baru pada sistem informasi yang ada atau pengembangan sistem informasi baru akan memanfaatkan pangkalan data tersebut. Hal tersebut dilakukan oleh RISTEKDIKTI dengan konsep PDPT dan ITS melakukan perancangan, implementasi serta memanfaatkan konsep yang sama dalam PDITS.

Latar belakang penelitian yang telah dilakukan dan diuraikan dalam makalah ini adalah usaha mengintegrasikan data-data dari berbagai sistem informasi. Sistem manajemen integrasi data berbasis web untuk mengumpulkan data-data dari berbagai lokasi berbeda sesuai dengan metadata yang ditetapkan [9] digunakan dalam penelitian ini. Alasannya karena banyak sistem informasi telah dikembangkan terlebih dahulu di ITS dan masing-masing memiliki metadata yang berbeda. Oleh karena itu PDITS akan menggabungkan data dengan format yang berbeda tersebut dan disesuaikan dengan format PDITS.

\section{Metodologi}

\subsection{Proses Bisnis PDITS (Pangkalan Data Terpadu ITS)}

Berdasarkan Peraturan Menteri Pendidikan dan Kebudayaan No. 49 Tahun 2011 tentang Statuta Institut Teknologi Sepuluh Nopember (ITS) yang diikuti dengan Peraturan Rektor ITS No. 3 Tahun 2012 tentang Organisasi dan Tata Kerja (OTK) ITS, Badan Teknologi dan Sistem Informasi (BTSI) termasuk dalam susunan organisasi ITS. Secara khusus, BTSI mempunyai fungsi mengelola, mengkoordinasikan, mengendalikan serta mengembangkan teknologi dan sistem informasi secara terpadu sesuai peraturan perundang-undangan di lingkungan ITS. BTSI berubah menjadi LPTSI (Lembaga Pengembangan Teknologi Sistem Informasi) sesuai dengan Peraturan Menteri Pendidikan dan Kebudayaan No. 86 Tahun 2013 tentang Organisasi dan Tata Kerja Institut Teknologi Sepuluh Nopember (ITS). Sebagian besar sistem informasi (Gambar 1) yang dipelihara oleh unit-unit kerja ITS mulai dikelola secara terpusat oleh LPTSI sejak tahun 2012 khususnya sistem yang dimanfaatkan oleh lintas unit kerja.

Sistem informasi yang ada dapat dikelompokkan menjadi klaster antara lain sebagai berikut: 
1) Klaster Akademik : sim akademik, sim ruang, sim beasiswa, sim kerja praktek, sim skem, elearning, online tracer study

2) Klaster Kepegawaian : sim kepegawaian, sim beban kerja dosen, sim kinerja karyawan

3) Klaster Manajemen : sim keuangan, sim pengelolaan aset, sim perencanaan anggaran, sim program kerja, sim honorarium, sim pendapatan, dll

4) Klaster Penelitian : sim penelitian, web personal dosen, digital library, e-journal pomits

5) Klaster Layanan : e-surat, e-caraka, dll

SISTEM INFORMASI MANAJEMEN TERPADU DI ITS

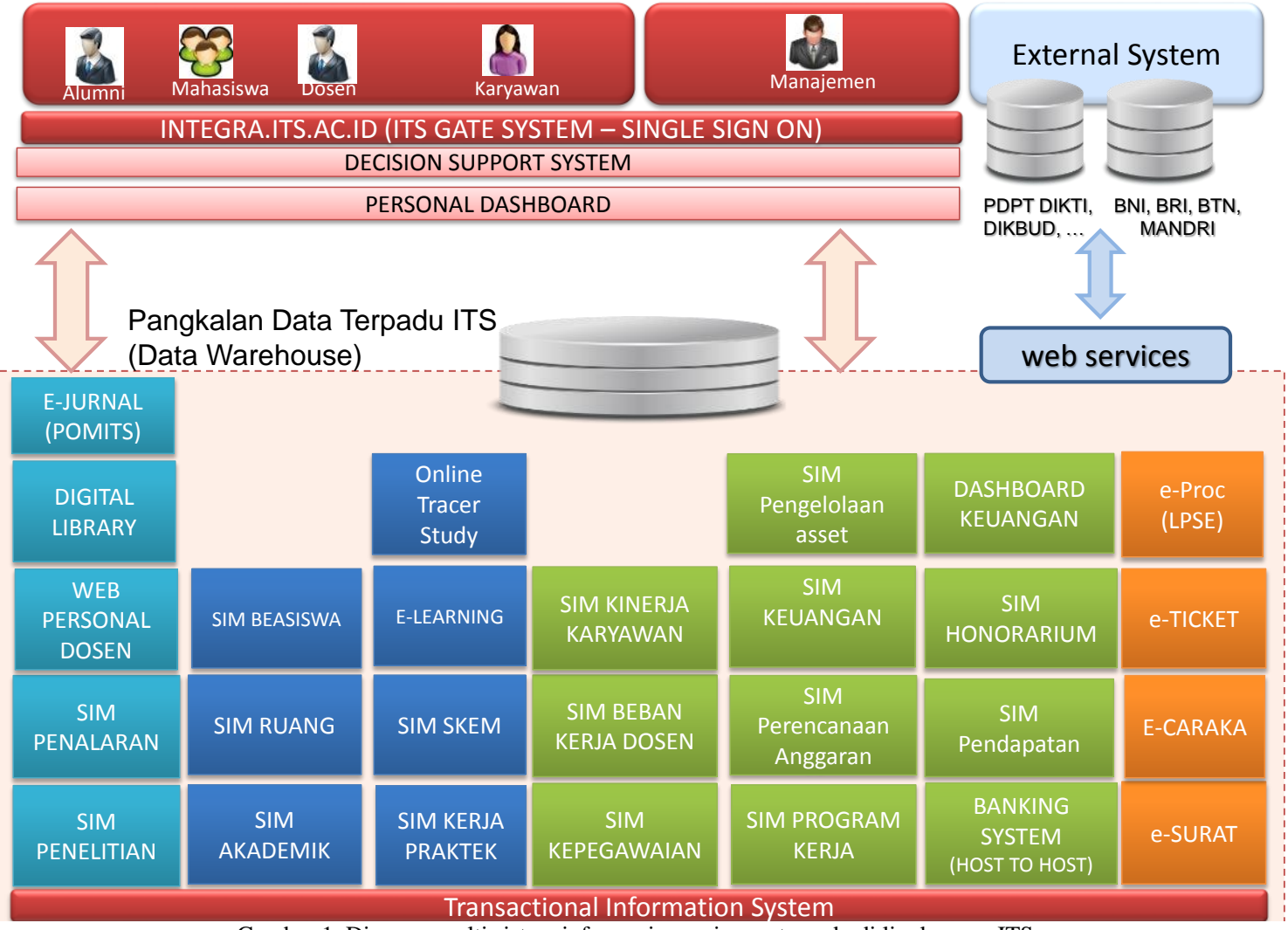

Gambar 1. Diagram multi sistem informasi manajemen terpadu di lingkungan ITS.

Beberapa sistem informasi dimungkinkan untuk dikembangkan maupun diintegrasikan dengan sistem yang lain oleh beberapa unit kerja. Namun sistem informasi utama bagi proses bisnis penyelenggaraan kegiatan pendidikan di ITS yaitu SIM Akademik (SIAKAD-ITS), SIM Kepegawaian (SIMPEG-ITS), SIM Keuangan terus dipelihara terpusat oleh LPTSI. Perancangan, implementasi serta pemanfaatan PDITS di periode tahun 2013-2015 difokuskan pada basis data SIAKAD-ITS dan SIMPEG-ITS (Gambar 2).

Berikut adalah proses-proses dalam Sistem Informasi Pangkalan Data ITS atau disebut PDITS:

1) Penarikan data dari multi sistem informasi penghasil data.

Perancangan sampai implementasi penarikan data mahasiswa dan dosen dari SIAKAD-ITS serta data dosen dari SIMPEG-ITS telah dilakukan di periode tahun 2013-2015. Data-data yang diambil dikategorikan sebagai data master (misal data pribadi mahasiswa), data transaksional (misal data pengambilan mata kuliah seorang mahasiswa di suatu semester) serta data referensi (misal data jalur masuk mahasiswa) berdasarkan pilihan filter tahun akademik, fakultas, jurusan serta program studi. 
Berdasarkan kebiasaan entri data oleh pengguna yaitu mahasiswa atau dosen, maka data-data dapat berubah di periode tertentu atau sepanjang tahun. Data pengambilan mata kuliah seorang mahasiswa di suatu semester termasuk sebagai data berubah di periode tertentu dalam SIAKAD-ITS. Data kegiatan dosen seperti penelitian atau pengabdian termasuk sebagai data berubah sepanjang tahun dalam SIMPEG-ITS. Oleh karena itu pengambilan data yang dapat berubah sepanjang tahun diatur agar dilakukan secara otomatis dari SIMPEG-ITS ke PDITS. Data-data mahasiswa yang berubah di periode tertentu masih memerlukan proses validasi dari Biro Akademik, Kemahasiswaan, dan Perencanaan ITS sehingga belum dilakukan pengaturan otomatis dari SIAKAD-ITS ke PDITS.

Pada Gambar 2 terlihat bahwa pengguna staf LPTSI sebagai pengelola PDITS dapat melakukan penarikan data PTK-Master yang akan melakukan aktivasi query ke basisdata SIMPEG-ITS atau data Mahasiswa-Master untuk aktivasi query ke backup basisdata SIAKAD-ITS. Tahap Penarikan Data ini dinyatakan sebagai Menu Impor PDITS yang dilakukan oleh pengguna staf LPTSI.

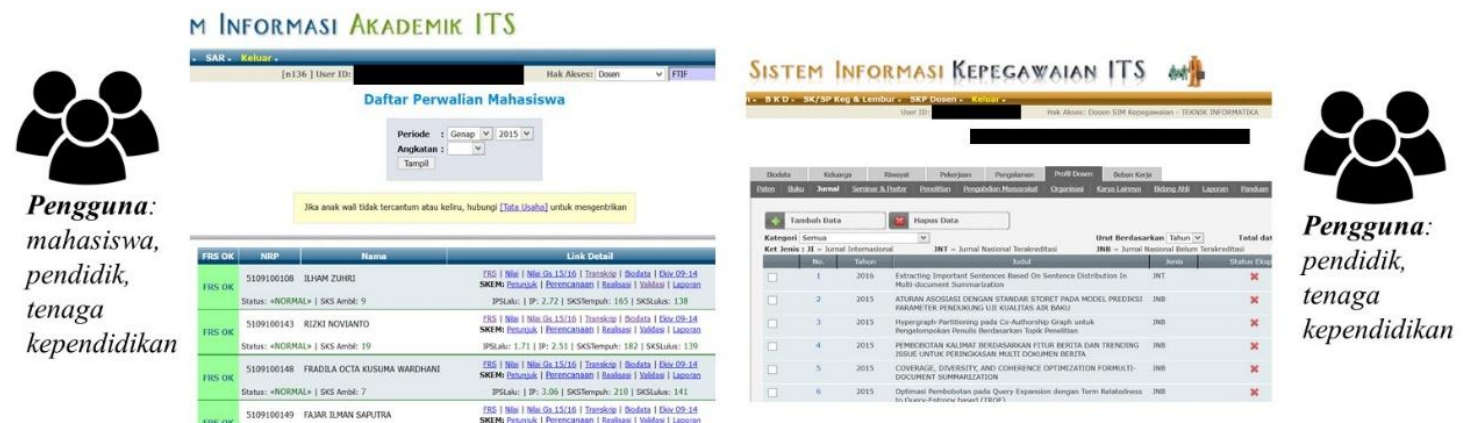

Sistem Informasi Akademik ITS (SIAKAD-ITS) Sistem Informasi Kepegawaian ITS (SIMPEG-ITS)

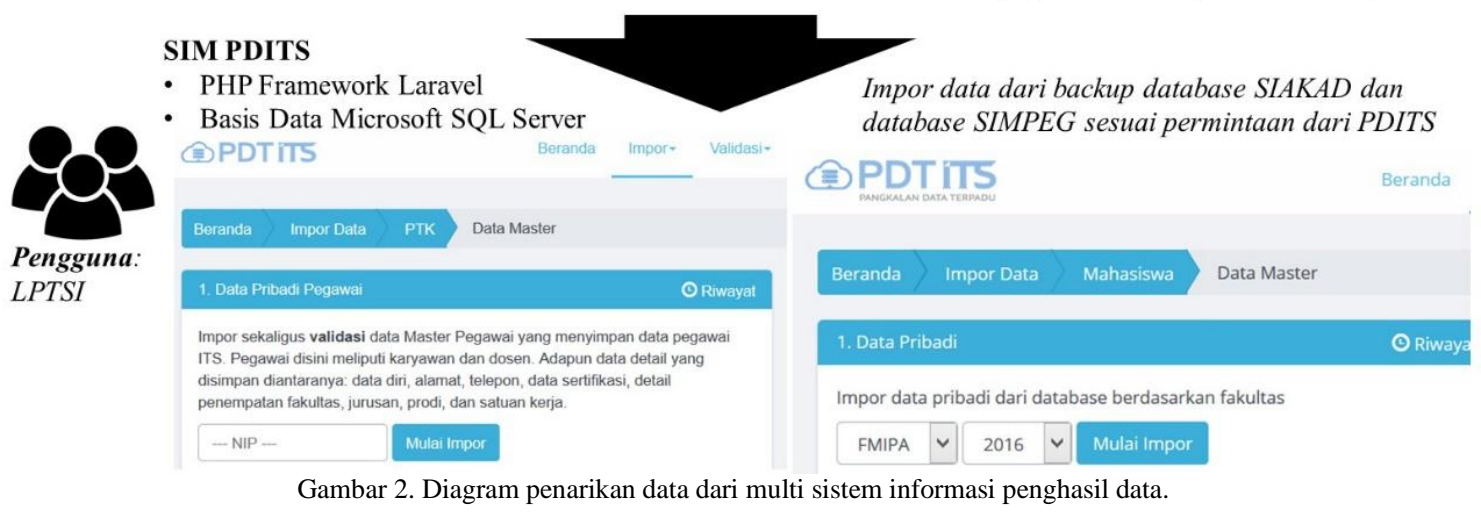

2) Validasi data dari multi sistem informasi.

Redudansi data dapat terjadi pada sistem informasi di suatu perguruan tinggi seperti data dosen khususnya Nomor Identitas Pegawai (NIP) di SIAKAD-ITS dan SIMPEG-ITS. Dimungkinkan pengangkatan awal dosen dilakukan langsung oleh unit kerja jurusan dan tidak terpusat secara institusional. Sehingga data dosen tersebut belum tersimpan di SIMPEG-ITS namun sudah tercatat dalam SIAKAD-ITS karena dosen yang bersangkutan akan mengampu suatu mata kuliah dan memiliki NIP sementara. Setelah dosen tersebut berstatus Pegawai Negeri Sipil (PNS) ITS maka data dosen akan tercatat di SIMPEG-ITS. Perbedaan data juga dapat disebabkan saat terjadi perubahan standarisasi NIP. Proses validasi data PDITS akan melakukan pengecekan ketidaksinkronan data NIP sekaligus menyesuaikan dengan NIDN (Nomor Induk Dosen Nasional) yang digunakan sebagai kode unik dosen pada PDPT. Tahap Validasi ini dinyatakan sebagai Menu Validasi PDITS yang dilakukan oleh pengguna staf LPTSI. 


\section{3) Perubahan data sesuai kebutuhan sistem informasi lain yang akan memanfaatkannya.}

Data-data yang tersimpan di PDITS dimanfaatkan di beberapa sistem informasi lainnya. Data PDITS perlu disesuaikan dengan format data pada sistem informasi tersebut, misal PDPT RISTEKDIKTI, SIM Penelitian ITS atau sistem lainnya, karena pengembangan sistem dapat dilakukan oleh tim yang berbeda. Pada tahap ini juga dilakukan pembaruan isi tabel web service sehingga pengembalian data ke sistem informasi lain yang memanggil service tersebut dapat lebih cepat.

Pada Gambar 3 adalah contoh aktivasi menu Proses-ARS-Mahasiswa-Baru yang artinya dilakukan perubahan data dari query beberapa tabel pada PDITS menjadi satu tabel view diistilahkan sebagai tag (tabel agregasi). Data-data pada tabel view tersebut akan ditampilkan di sistem Data Statistik ITS dengan lebih cepat karena tidak perlu melakukan proses join tabel. Standarisasi pembentukan tabel view Data Statistik ITS adalah satu tabel tag akan berkorelasi dengan tampilan satu grafik.

\section{SIM PDITS}

- PHP Framework Laravel

- Basis Data Microsoft SQL Server

\section{Data Statistik ITS}

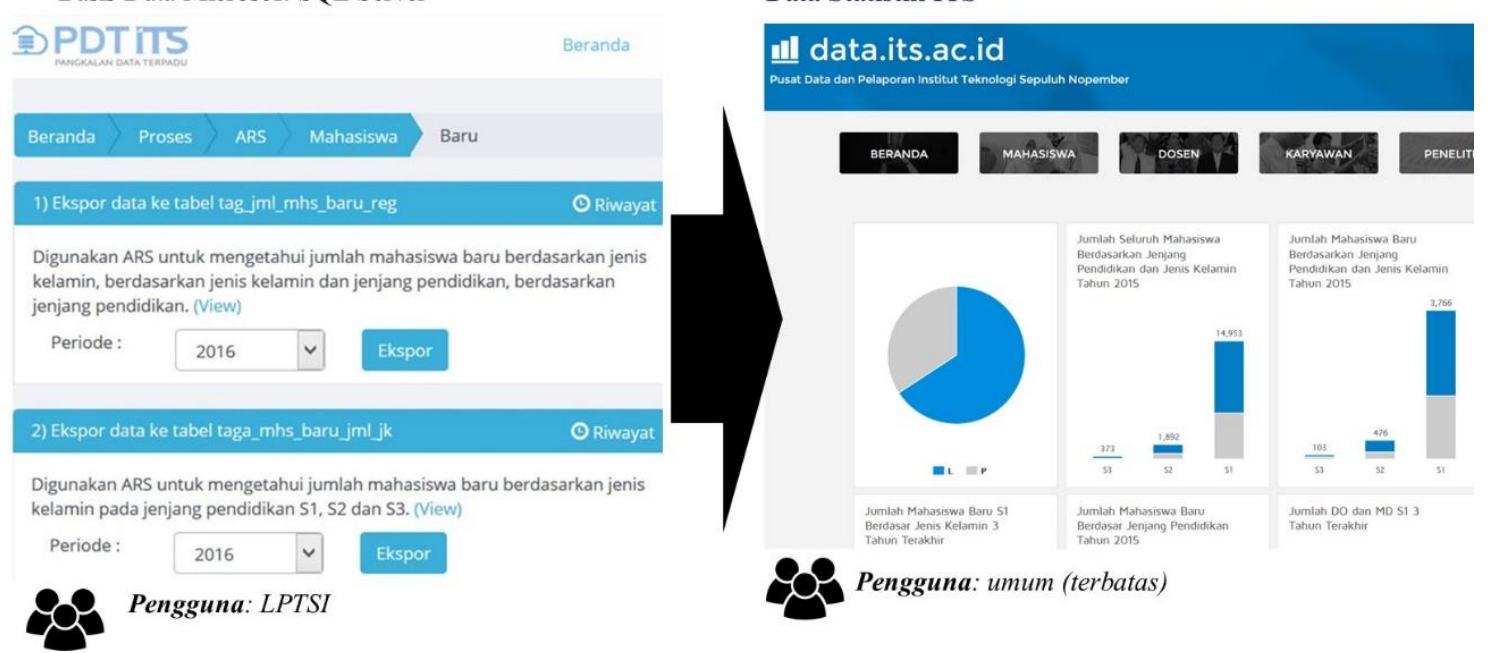

Gambar 3. Diagram perubahan data sesuai kebutuhan sistem informasi lain.

\subsection{Manajemen Data PDITS}

Data-data yang disimpan dalam tabel PDITS dikategorikan sebagai tabel master, tabel transaksional dan tabel referensi ditunjukkan pada Tabel 1 dan Tabel 2. Suatu entitas data misal entitas mahasiswa atau dosen hanya akan memiliki satu data pada tabel master. Namun entitas tersebut akan memiliki lebih dari satu data di tabel transaksional. Sebagai contoh data mahasiswa akan memiliki data lebih dari satu semester, dan di setiap semester akan memiliki lebih dari satu mata kuliah yang diambil.

Beberapa jenis data belum tersimpan di dalam sistem informasi, sebagai contoh data jumlah peminat setiap program studi beserta status jalur masuk serta jumlah yang diterima. Berdasarkan Peraturan Menteri Riset, Teknologi, dan Pendidikan Tinggi (Permenristekdikti) No. 2 Tahun 2015 tentang Penerimaan Mahasiswa Baru Program Sarjana pada Perguruan Tinggi Negeri maka pola penerimaan mahasiswa Sarjana ITS dilakukan melalui Seleksi Nasional Masuk Perguruan Tinggi Negeri (SNMPTN), Seleksi Bersama Masuk Perguruan Tinggi Negeri (SBMPTN), dan Seleksi Mandiri Program Kemitraan dan Mandiri (PKM). Untuk setiap pola penerimaan memiliki sistem tersendiri sehingga Biro Akademik, Kemahasiswaan, dan Perencanaan ITS melakukan pengolahan manual untuk mendapatkan data jumlah peminat, diterima dan daftar ulang. Data-data tersebut sering diminta oleh program studi antara lain saat pembuatan borang 
akreditasi nasional maupun internasional serta penjaminan mutu internal atau eksternal. Oleh karena itu untuk mendukung konsep kemudahan entri bagi pengguna maka beberapa jenis data akan disimpan dalam PDITS melalui unggah berkas berdasarkan aturan tertentu (ditunjukkan pada Tabel 3).

Tabel 1. Data-data mahasiswa diambil dari SIAKAD-ITS sebagai sumber penghasil data.

\begin{tabular}{|c|c|c|}
\hline No & Jenis Data & Keterangan \\
\hline 1 & Master & $\begin{array}{l}\text { Data pribadi mahasiswa, foto, status mahasiswa asing mendukung visi ITS menjadi universitas bereputasi } \\
\text { internasional }\end{array}$ \\
\hline 2 & Master & $\begin{array}{l}\text { Data mata kuliah yang ditawarkan berdasarkan periode kurikulum (kode, nama, jumlah sks, mata kuliah } \\
\text { prasyarat, nilai minimal kelulusan dalam huruf, semester pengambilan) }\end{array}$ \\
\hline 3 & Transaksional & $\begin{array}{l}\text { Mata kuliah yang diambil oleh mahasiswa di suatu semester beserta nilai-nilainya termasuk nilai gabungan } \\
\text { Indeks Prestasi Semester (IPS) dan Indeks Prestasi Kumulatif (IPK). Setiap mata kuliah yang ditawarkan } \\
\text { memiliki minimal empat nilai evaluasi. }\end{array}$ \\
\hline 4 & Transaksional & Data status mahasiswa: aktif, cuti, mengundurkan diri, dll pada suatu semester berlangsung. \\
\hline 5 & Transaksional & $\begin{array}{l}\text { Data tugas akhir mahasiswa: judul, dosen pembimbing. Data untuk mahasiswa angkatan lama }(<2010 \\
\text { belum ada kewajiban entri data tugas akhir) akan diunggah melalui berkas: jenis kelamin, tanggal wisuda, } \\
\text { lama studi, IPK, predikat kelulusan, dosen pembimbing, nilai TOEFL. }\end{array}$ \\
\hline 6 & Transaksional & $\begin{array}{l}\text { Data kegiatan non akademik mahasiswa ITS (SKEM, Satuan Kegiatan Ekstrakurikuler): penalaran dan } \\
\text { keilmuan, minat dan bakat, organisasi dan kepemimpinan, kepedulian sosial }\end{array}$ \\
\hline
\end{tabular}

Tabel 2. Data-data dosen diambil dari multi sistem informasi (SIAKAD-ITS dan SIMPEG-ITS) sebagai sumber penghasil data.

\begin{tabular}{lll}
\hline No & \multicolumn{1}{c}{$\begin{array}{c}\text { Jenis Data } \\
\text { (Sumber) }\end{array}$} & \\
\hline 1 & $\begin{array}{l}\text { Master } \\
\text { (SIMPEG-ITS) }\end{array}$ & $\begin{array}{l}\text { Data pribadi dosen (pendidik) termasuk tenaga kependidikan nantinya. Data yang disimpan diantaranya } \\
\text { data diri, alamat, telepon, data sertifikasi, detail satuan kerja. }\end{array}$ \\
2 & $\begin{array}{l}\text { Master } \\
\text { (SIMPEG-ITS) }\end{array}$ & $\begin{array}{l}\text { Data Satuan Kerja yang menyimpan riwayat perubahan kebijakan daftar satuan kerja ITS pada tiap-tiap } \\
\text { periode berlakunya. }\end{array}$ \\
3 & $\begin{array}{l}\text { Transaksional } \\
\text { (SIAKAD-ITS) }\end{array}$ & $\begin{array}{l}\text { Mata kuliah yang diampu oleh dosen dan ditawarkan bagi mahasiswa di suatu semester. Suatu mata kuliah } \\
\text { dapat diampu oleh lebih dari satu dosen sebagai tim pengajar. }\end{array}$ \\
4 & $\begin{array}{l}\text { Transaksional } \\
\text { (SIAKAD-ITS) }\end{array}$ & Hasil kuesioner mahasiswa terhadap seorang dosen tentang kualitas pelaksanaan suatu perkuliahan. \\
5 & $\begin{array}{l}\text { Transaksional } \\
\text { (SIMPEG-ITS) }\end{array}$ & $\begin{array}{l}\text { Riwayat pendidikan dosen, riwayat pangkat dan jabatan fungsional \& struktural, status aktivitas (aktif, } \\
\text { tugas belajar, diperbantukan, wafat, dll), riwayat absensi kehadiran. }\end{array}$ \\
& $\begin{array}{l}\text { Transaksional } \\
\text { (SIMPEG-ITS) }\end{array}$ & Riwayat kegiatan penelitian, publikasi dan pengabdian dosen serta keanggotan dalam laboratorium. \\
\hline
\end{tabular}

Tabel 3. Data-data yang diunggah ke PDITS melalui berkas dengan aturan tertentu.

No

\section{Keterangan}

1. Data jumlah peminat, diterima dan daftar ulang untuk setiap program studi per tahun akademik

2. Data mahasiswa lulus: tanggal lulus, IPK, sks lulus, nomor \& tanggal SK yudisium, nomor ijazah, nilai TOEFL

3. Data mahasiswa penerima beasiswa: nama dan asal beasiswa, tanggal awal - tanggal akhir berlaku

4. Data laboratorium yang dimiliki oleh program studi ITS beserta data ketua, anggota dan bidang ahli masing-masing

5. Data homebase dosen yang terdaftar di PDDIKTI sesuai program studi 


\subsection{Integrasi Data PDITS}

Berdasarkan keberhasilan integrasi PDPT dengan sistem informasi di perguruan tinggi di seluruh Indonesia [4] [5] dan integrasi data geografis dari beberapa lokasi berbasis web [9], maka sistem PDITS juga diimplementasikan berbasis web. Pada sistem PDITS diatur beberapa menu yang menjadi tahapan utama yaitu Impor, Validasi, dan Proses (Gambar 4). Aktivasi menu pada tahap Impor akan mengeksekusi query ke database sistem informasi penghasil data seperti SIAKAD-ITS dan SIMPEG-ITS. Data-data yang bisa dilakukan proses Impor ditunjukkan pada Tabel 1, Tabel 2, dan Tabel 3. Tahap Impor akan melakukan duplikasi data dari basis data sistem informasi asal ke basis data PDITS. Tahap selanjutnya adalah Validasi yaitu pengecekan data pada basis data PDITS sesuai aturan yang berlaku. Jika ada data yang tidak sesuai maka data-data tersebut akan ditampilkan di sistem PDITS sehingga staf LPTSI dapat melakukan perubahan data valid. Kemudian tahap terakhir yaitu Proses adalah melakukan perubahan data pada basisdata PDITS. Pada tahap proses data-data dari beberapa tabel dalam PDITS akan dilakukan proses join (agregasi data) sesuai dengan filter query menjadi satu atau beberapa tabel (disebut tabel view). Tabel View tersebut akan ditampilkan atau disinkronkan dengan web service ke sistem informasi lain yang membutuhkan. Contoh sistem-sistem informasi lain yang menggunakan PDITS dijelaskan pada bagian berikutnya tentang pembahasan dan hasil. Semua aktivasi menu Impor, Validasi dan Proses dilakukan oleh staf LPTSI. Dikarenakan keterbatasan query maka setiap aktivasi menu dimungkinkan adanya filter untuk mengurangi pengiriman data dari basisdata sistem informasi asal ke basisdata PDITS atau dari basisdata PDITS ke basisdata sistem informasi yang akan memanfaatkan data.

\section{Hasil dan Pembahasan}

PDITS dikembangkan dengan bahasa pemrograman PHP framework Laravel menggunakan database SQL Server sejak tahun 2013 sampai sekarang oleh Lembaga Pengembangan Teknologi Sistem Informasi (LPTSI) yang bertanggung jawab terhadap sistem informasi di ITS. Berdasarkan ujicoba pengambilan data dari server basisdata SIAKAD-ITS dikarenakan jumlah data yang cukup besar (asumsi jumlah mahasiswa aktif ITS per semester 15.000 dan setiap mahasiswa minimal mengambil empat mata kuliah, untuk transaksi akademik mahasiswa akan terkirim $>60.000$ data), maka volume pengiriman data antar server dikurangi dengan adanya penambahan filter (contoh pada Gambar 4: tahun, fakultas, program studi, dll).

Pada Gambar 4 ditunjukkan antarmuka yang digunakan oleh staf LPTSI untuk mengelola PDITS. Tahap awal dilakukan Impor data atau penarikan data mahasiswa dari SIAKAD-ITS. Data-data yang diimpor ditunjukkan pada Tabel 1. Setelah Tahap Impor maka dilakukan Tahap Validasi dan berlanjut ke Tahap Proses sesuai kebutuhan. Proses pada Gambar 4 adalah penggunaan data PDITS untuk keperluan pelaporan DIKTI yaitu PDPT.

Fokus pengembangan di tahun 2016 dan seterusnya adalah pemanfaatan PDITS untuk sistem informasi lain selain bidang akademik, kepegawaian dan penelitian. Pada tahun 2015 PDITS dimanfaatkan untuk melakukan proses pelaporan data ITS ke PDPT dan bisa mengurangi waktu pelaksanaan pelaporan dari satu bulan menjadi dua minggu. Pelaporan yang sebelumnya harus dilakukan oleh staf teknis dengan kemampuan minimal pemrograman web serta pemrosesan query, maka dengan PDITS proses tersebut dapat dibantu oleh staf non teknis karena tahapan pelaporan sudah dipandu oleh sistem. Pada tahun 2016 pelaporan sudah dilakukan oleh staf non teknis (menggunakan antarmuka PDITS di Gambar 4) yang telah diberikan pelatihan penggunaan PDITS serta terus berkoordinasi dengan staf teknis. Solusi demikian membantu ITS khususnya LPTSI yang memiliki keterbatasan sumber daya staf teknis. Staf LPTSI melakukan pemeliharaan PDITS secara manual setidaknya satu bulan sekali dan selambatnya setahun dua kali sesuai dengan periode pelaporan PDPT.

Selain untuk pelaporan PDPT, PDITS telah dimanfaatkan oleh sistem informasi lain di lingkungan ITS: 


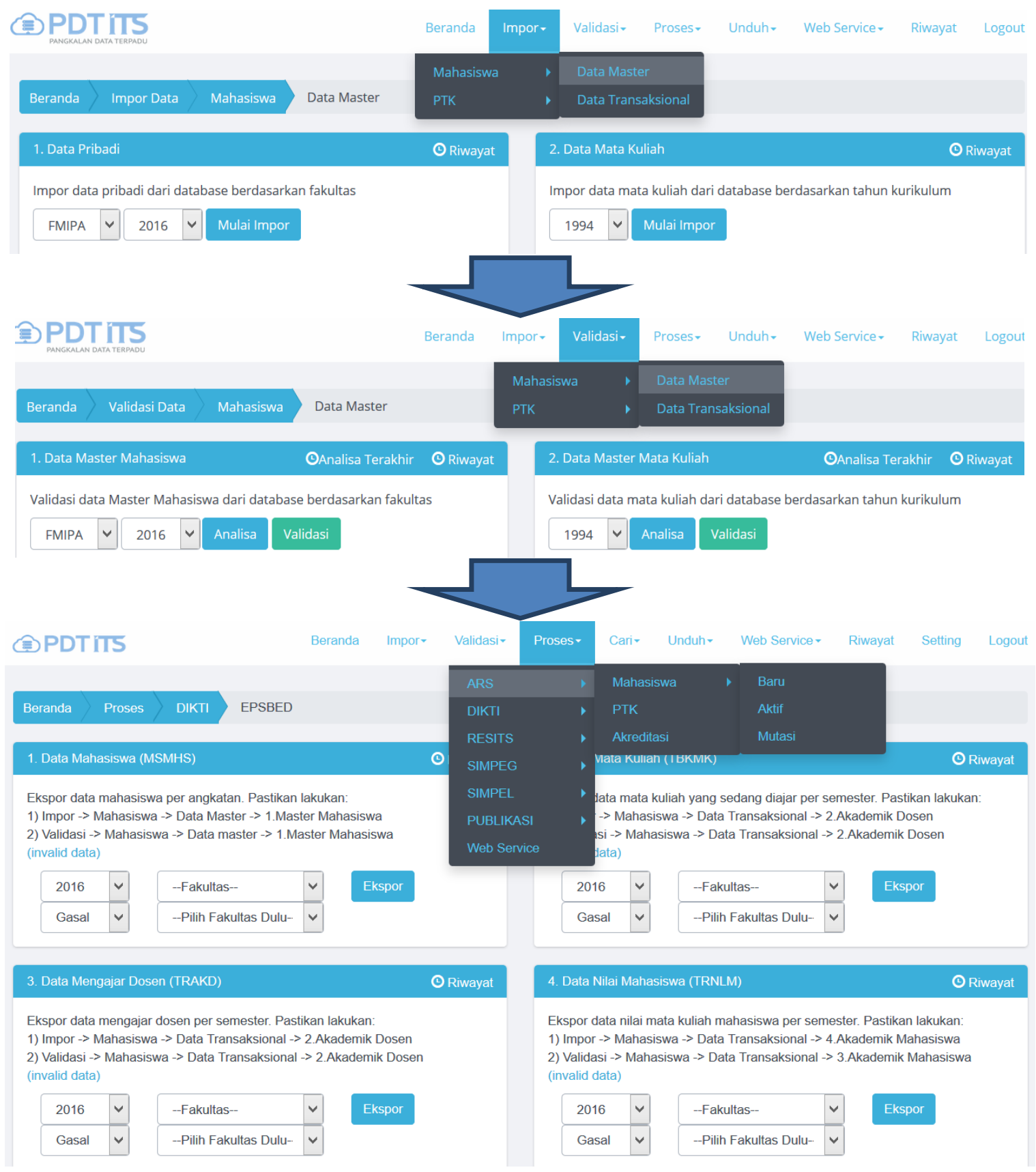

Gambar 4. Contoh antar muka sistem pangkalan data terpadu ITS (PDITS) untuk perubahan kebutuhan PDPT

1) Untuk menampilkan profil atau web personal dosen yang disebut sebagai Resource ITS (ResITS**). Profil dosen menampilkan data-data kegiatan dosen utamanya penelitian seperti publikasi jurnal/ seminar/buku dan pengabdian. Data-data tersebut dientri melalui SIMPEG-ITS dan digunakan dalam

*** http://resits.its.ac.id/ 
penghitungan beban kerja dosen untuk pengukuran kinerja. Dosen dapat terbantu karena tidak perlu melakukan entri data berulang kali. Pengguna umum di luar lingkungan ITS dapat mengakses informasi profil dosen dalam ResITS tanpa melalui proses autentikasi. Sinkronisasi data dari SIMPEGITS dilakukan secara otomatis oleh sistem dengan PDITS pada periode yang telah ditentukan. Apabila terdapat data-data kegiatan dosen dihapus dari SIMPEG-ITS maka saat sinkronisasi akan diberikan status penanda pada data-data tersebut di PDITS (soft-delete). Sehingga data-data yang memiliki status soft-delete tidak terlihat melalui ResITS.

2) Untuk menampilkan data Statistik-ITS †† utamanya terkait calon mahasiswa seperti jumlah peminat, diterima, daftar ulang, rata-rata nilai SBMPTN; atau jumlah mahasiswa aktif berdasarkan jenjang pendidikan, jenis kelamin, penerima beasiswa; atau distribusi nilai IPK mahasiswa, status mahasiswa lulus/ mengundurkan diri, dan statistik lain. Sumber data utamanya berasal dari SIMAKAD-ITS. Pengguna umum juga dapat mengakses data statistik tersebut tanpa melalui proses autentikasi, meskipun pada pengembangan berikutnya akan disediakan informasi statistik untuk pengguna terbatas. Perubahan data sebagai bagian dari proses-proses dalam PDITS dilakukan untuk memenuhi kebutuhan informasi Statistik-ITS. Pada proses perubahan data dilakukan transformasi data-data transaksional menjadi data bersifat agregasi yang disimpan dalam satu tabel tertentu. Saat pengguna memilih untuk melihat suatu informasi statistik tertentu maka langsung data diambil dari tabel agregasi statistik yang berkesesuaian sehingga pengembalian grafik statistik akan lebih cepat. Untuk saat itu proses perubahan data masih dilakukan staf LPTSI melalui aplikasi PDITS sehingga ada kemungkinan informasi pada Statistik-ITS sedikit berbeda. Pada pengembangan selanjutnya akan dilakukan otomasi sehingga apabila terjadi perubahan data PDITS maka tabel agregasi juga berubah sehingga tidak ada perbedaan data pada Statistik-ITS.

3) Untuk sinkronisasi data master dosen sebagai pelaksana dalam kegiatan penelitian atau pengabdian di sistem informasi penelitian ITS (SIMPEL-ITS*). Pengguna SIMPEL-ITS hanya terbatas dosen atau staff ITS yang membuat ajuan serta monitoring pelaksanaan kegiatan. SIMPEL-ITS juga digunakan oleh Beberapa skema kegiatan memiliki prasayarat bagi dosen pelaksana dengan minimal jenjang pendidikan maupun jabatan fungsional tertentu. Data-data tersebut aktif dipelihara dalam SIMPEGITS. PDITS yang telah tersinkronisasi dengan SIMPEG-ITS akan menyediakan data-data tersebut untuk SIMPEL-ITS. Kemudian data-data kegiatan penelitian-pengabdian yang tersimpan di SIMPELITS akan otomatis tersinkronisasi ulang ke PDITS dan memperbarui data SIMPEG-ITS. Hal tersebut menunjukkan bahwa sinkronisasi data melalui PDITS telah membantu integrasi multi sistem informasi dan pengguna akan lebih terbantu karena tidak perlu melakukan entri data berulang kali.

LPTSI pada periode 2012-2016 juga telah membantu unit kerja di ITS untuk mengembangkan Sistem Penjaminan Mutu Internal (SPMI ${ }^{\S}$ ). Isian data-data pada SPMI antara lain terkait statistik ITS dan kegiatan penelitian/pengabdian. Namun isian data-data tersebut belum terintegrasi dengan PDITS karena mas pengembangan sistem saat itu berjalan bersamaan dengan pengembangan PDITS. Untuk kedepannya masih banyak sistem informasi lain di lingkungan ITS yang dapat diintegrasikan dengan PDITS sehingga pemanfaatan data dapat lebih maksimal.

\section{Kesimpulan}

PDITS telah diimplementasikan sebagai pangkalan data terpadu dari sumber data mahasiswa dan dosen karena dua entitas tersebut merupakan data utama dalam penyelenggaraan pendidikan ITS. Kemudian data-data PDITS telah dimanfaatkan ke beberapa sistem informasi untuk mendukung integrasi informasi. PDITS telah terbukti membantu mengurangi proses entri data berulang kali. Dikarenakan PDITS menjadi pangkalan data terpadu untuk mendukung integrasi multi sistem informasi, maka fitur sistem PDITS khususnya otomasi sinkronisasi perlu terus dipelihara dan dikembangkan.

\footnotetext{
${ }^{\dagger}$ https://data.its.ac.id/

\$ttps://simpel.its.ac.id/

$\S \S$ http://spmi.its.ac.id/
} 
Manfaat dari penggunaan PDITS adalah memudahkan LPTSI sebagai pengelola sistem informasi di lingkungan ITS untuk melakukan pengumpulan data dari multi sistem informasi penghasil data. Diharapkan basisdata PDITS akan menjadi pangkalan data terpadu yang dapat dimanfaatkan ulang datadatanya oleh sistem-sistem informasi lain. Namun keterbatasan PDITS pada saat ini adalah belum banyak sistem informasi yang telah ditarik datanya ke basisdata PDITS. Selain itu penarikan data ke SIAKAD-ITS masih diambil dari backup data sehingga terjadi sedikit perbedaan data. Hal tersebut dikarenakan proses mutasi mahasiswa seperti pengambilan cuti, mengundurkan diri dan semacamnya belum dilakukan di SIAKAD-ITS. Permasalahan-permasalahan tersebut yang menjadi pengembangan PDITS selanjutnya.

\section{Acknowledgement}

Pengembangan aplikasi PDITS dimulai sejak tahun 2012 oleh Pusat Data dan Pelaporan Lembaga Pengembangan Teknologi Sistem Informasi ITS (Pusdata LPTSI). LPTSI periode 2012-2016 dengan ketua lembaga Achmad Affandi terdiri dari empat pusat sebagai berikut: (i) Pusat Pengelolaan dan Layanan TIK dengan koordinator Arief Rahman, (ii) Pusat Pengembangan SI dengan koordinator Umi Laili Yuhana, (iii) Pusat Data dan Pelaporan dengan koordinator Diana Purwitasari, dan (iv) Pusat Infastruktur dan Keamanan Informasi dengan koordinator Bambang Setiawan.

Pemanfaatan PDITS untuk sistem informasi lain di lingkungan ITS seperti ResITS, Statistik-ITS, SIMPEL-ITS juga dikembangkan oleh Pusdata LPTSI pada tahun 2015-2016.

Tim aplikasi PDITS adalah, sesuai dengan urutan penulisan nama, staf LPTSI Agus Nugroho, Arief Pramono, Ida Yagsa, Inayati Fajriyah, dan Mochamad Yasin beserta mahasiswa Teknik Informatika yang mengikuti internship pada saat itu Aida Muflichah, AnNisa' Hajar Pelina, Fatahillah Alvarisi, Ifan Iqbal, Royyan Bachtiar, Wahyu Widodo dan Yoga Pratama Aliarham.

Pemeliharaan aplikasi PDITS terus dilakukan sampai sekarang oleh LPTSI untuk periode 2016-2020 dengan ketua lembaga Febriliyan Samopa dan (i) Pusat Pengelolaan dan Layanan TIK oleh Hanim Maria Astuti, (ii) Pusat Pengembangan SI oleh Anny Yuniarti, (iii) Pusat Infastruktur dan Keamanan Informasi oleh Royyana Muslim Ijtihadie.

\section{Daftar Rujukan}

[1] T. R. Muzzammil, R. V. H. Ginardi dan D. Purwitasari, "Modul Klasifikasi Aduan dengan Pendekatan Kemiripan Teks pada Aplikasi Perangkat Bergerak Suara Warga (SURGA) Kota Kediri,” Jurnal Teknik ITS, vol. 5, no. 1, pp. A52-A57, 2016.

[2] S. Nurmiati dan H. Munandar, "Sistem Informasi Kegiatan Akademik untuk Akreditasi Program Studi Berbasis Web Studi Kasus Program Studi Manajemen Sumberdaya Perairan - IPB,” Jurnal Sistem Informasi, vol. 5, no. 5, pp. 514-522, 2016.

[3] A. Solichin dan Z. A. Hasibuan, "Pemodelan Arsitektur Teknologi Informasi Berbasis Cloud Computing untuk Institusi Perguruan Tinggi di Indonesia," dalam Seminar Nasional Teknologi Informasi \& Komunikasi Terapan (SEMANTIK), 2012.

[4] B. L. Panggabean, A. A. Ilham dan A. Lawi, "Integrasi Pangkalan Data Perguruan Tinggi dengan Teknologi Web Service," Jurnal Pascasarjana UNHAS, 2013.

[5] E. W. Kenali dan H. Fathoni, "Desain dan Implementasi Services Provider Berbasis Web Services Push Pangkalan Data Perguruan Tinggi pada Sistem Informasi Akademik Politeknik Negeri Lampung," dalam Seminar Bisnis \& Teknologi (SEMBISTEK), 2014.

[6] P. Ziegler dan K. R. Dittrich, "Three Decades of Data Integration --- All Problems Solved?," dalam Building the Information Society, Boston, MA, Springer US, 2004, pp. 3--12.

[7] K. Jakimoski, "Challenges of Interoperability and Integration in Education Information Systems," International Journal of Database and Theory and Application, vol. 9, no. 2, pp. 33-46, 2016.

[8] PeopleSoft Campus Solutions, Oracle, “The Connected Campus: Leveraging the Value of a Modern Student System,” 2011. [Online].

[9] El Sawah, S., Hicks, A., Manger, P., Athanasiadis, I.N., Croke, B.F.W., Jakeman, A.J., "A web-based platform for integrated groundwater data management," dalam 19th International Congress on Modelling and Simulation, Perth, Australia, 2011. 
Diana Purwitasari et al. / Jurnal Sisfo Vol.06 No.01 (2016) 65-76

Halaman ini sengaja dikosongkan 